Article

\title{
Evaluation of Design Parameters on Drying of Kiwi Fruit
}

\author{
Filiz Ozgen ${ }^{1, *}$ and Nevin Celik ${ }^{2}$ D \\ 1 Department of Mechanical Engineering, Faculty of Technology, Firat University, Elaziğ 23119, Turkey \\ 2 Department of Mechanical Engineering, Faculty of Engineering, Firat University, Elaziğ 23119, Turkey; \\ nevincelik23@gmail.com \\ * Correspondence: filizozgen@gmail.com; Tel.: +90-505-478-7755
}

Received: 21 November 2018; Accepted: 19 December 2018; Published: 20 December 2018

\begin{abstract}
In this study, the drying of kiwi fruit in a convective dryer is examined experimentally. Air velocity, thickness of the slices and drying time are the varied parameters in drying process. In the experimental study, kiwi slices having thickness of 4 and $8 \mathrm{~mm}$ are dried in the dryer under the conditions of $45^{\circ} \mathrm{C}$ temperature of the drying air, $10 \%$ relative humidity and $0.5-1.5 \mathrm{~m} / \mathrm{s}$ drying air velocity. In addition to the tests, the effects of mentioned drying parameters on drying are analyzed by ANOVA (Analysis of Variance) method to find the contribution rate of each parameter. For this aim, an orthogonal array is arranged by using Taguchi design of experiment method. As the results of experiments and variance analysis, it has been determined that, drying air velocity plays a significant effect on total drying time. The minimum drying time $(225 \mathrm{~min})$ is achieved for $1.5 \mathrm{~m} / \mathrm{s}$ for $4 \mathrm{~mm}$ slices, and the maximum drying time $(750 \mathrm{~min})$ is achieved for $0.5 \mathrm{~m} / \mathrm{s}$ for the kiwi sample sliced $8 \mathrm{~mm}$ thick. It is also concluded that, working with the convective dryer at different velocities is advantageous in terms of preserving brightness and color quality.
\end{abstract}

Keywords: drying; kiwi; air velocity; slice thickness

\section{Introduction}

Since agricultural products produced in large quantities are not immediately consumed, the durability times are very short. Keeping these products fresh is possible as a result of some special operations. Drying is the leading of the processes that intended to extend the economic life of agricultural products without losing their nutritious properties during the time elapsed until the moment of consumption of the products. Drying is defined as a method of industrial scale protection with heated air to reduce water activity by reducing the water content of fruits and vegetables and thus minimize biochemical, chemical and microbiological degradation [1]. Drying is a process in which $80-95 \%$ of water within the agricultural products is reduced to $10-20 \%$ and maintained for a long time. However, the quality characteristics such as taste, appearance, color, nutritional value should be changed as little as possible and when the water is added on them for cooking, they should be able to absorb the water as close as to the amount they had when they were fresh. Drying of kiwi fruit is often followed by physical and chemical changes which dramatically influence the process itself. One of the most important consequences of these changes is shrinkage: a volume reduction, coupled with shape and porosity changes and hardness increase. Such phenomena could also be followed by surface cracking. Therefore, shrinkage has to be avoided because such physical changes contribute in general to reduce the quality perceived by the end consumer of dehydrated products, traditionally consumed fresh. Obvious exceptions are represented by foods, like dried plums and dates, usually eaten shrunken.

The drying process itself is actually a heat and mass transfer phenomenon and drying agricultural products with solar energy has been used from ancient times to present as a method of product storage. 
The quality of food is drastically reduced in the solar drying due to rain, dust that wind causes, dirt and contact of various creatures such as insects and flies. Overcoming these problems is possible when the drying process is carried out in the designed closed systems. In the drying processes in natural environments, long periods of drying, the product being vulnerable to environmental influences and the decrease in nutritional value cause loss of quality and economic value in products. For this reason, the drying process with artificial dryers that have special purposes not only shortens the drying time but also ensures to get a higher quality and clean product with a long shelf life. Drying of a wide variety of fruits and vegetables is provided with artificial dryers; for instance, apricots [2], bananas [3], apples [4], potatoes [5], onions [6], eggplant [7], pear [8] are only some of the vegetables and fruits dried in artificial dryers and analyzed for drying.

In this study, the kiwifruit is analyzed for drying and it is a fruit species grown in different regions of Turkey. Kiwifruit contains $80 \%$ water, $20 \%$ dry matter and is rich in vitamin C. $100-400 \mathrm{mg}$ of vitamin $C$ is found in $100 \mathrm{~g}$ of the said fresh fruit [9]. Vitamin C content is an important factor that makes kiwifruit a worthy and sought-after fruit. The proportion of vitamin $C$ in the fruit varies according to environmental conditions, the state of development and maturation, and even where the fruit is situated on the plant [9]. The mineral content values of kiwifruit are shown in Table 1 [9].

Table 1. Mineral content of kiwi fruits organic ( $\mathrm{mg} / \mathrm{kg}$ ) [9].

\begin{tabular}{cc}
\hline Indices & Kiwi \\
\hline$P$ & $2640 \pm 111$ \\
$K$ & $17.418 \pm 639$ \\
$\mathrm{Ca}$ & $1512 \pm 15$ \\
$\mathrm{Mg}$ & $864 \pm 41$ \\
$\mathrm{Na}$ & $242 \pm 12$ \\
$\mathrm{Fe}$ & $16.1 \pm 0.8$ \\
$\mathrm{Mn}$ & $22.4 \pm 1.2$ \\
$\mathrm{Cu}$ & $1.14 \pm 0.1$ \\
$\mathrm{Zn}$ & $10.8 \pm 0.3$ \\
$B$ & $6.11 \pm 0.3$ \\
$\mathrm{~S}$ & $164 \pm 5.7$ \\
\hline
\end{tabular}

The kiwi fruit is used to obtain fruit juice and is consumed freshly. Additionally, it is used in the food industry for making pastry and dessert. Besides the nutritional value of kiwifruit, it is also used in medicine. Analyzes in China have shown that certain substances in fruit juice prevent factors that cause cancer. When used in combination with certain medicinal drinks, it has been utilized as breath spray against asthma and cough [10-13].

There are some works in the literature that examine the effects of parameters during drying of agricultural products such as humidity, air temperature and flow rate. Singh and Pandey [14] have examined the effects of drying conditions on the drying behavior of sweet potato in a drying cabinet. In a dryer, the drying behavior of sweet potatoes of 5,8 and $12 \mathrm{~mm}$ thick was investigated for various air temperatures $\left(50-90{ }^{\circ} \mathrm{C}\right)$ and air velocity $(1.5-5.5 \mathrm{~m} / \mathrm{s})$. Brasiello et al. [7], analyzed the evolution of the water content profiles inside cylindrical samples of eggplant during dehydration at 50,60 and $70{ }^{\circ} \mathrm{C}$ using a mathematical model which takes into account shrinkage effects. Guine and Fernandes [15] performed drying behaviors of three different kinds of chestnuts under isothermal conditions at 70, 80 and $90^{\circ} \mathrm{C}$. Karim and Hawlader [16] developed a different mathematical simulation for the drying of banana by examining the drying characteristics of the product. Maskan [17] studied the color change of kiwifruit during the drying of the product with hot air and microwave. Proietti et al. [8], evaluated the water transport mechanism and shrinkage in pear during process carried out at 45,50 and $55^{\circ} \mathrm{C}$ by portable Nuclear Magnetic Resonance (NMR) with the aim of optimizing the process. Velic et al. [18] investigated the effect of the air velocity on the drying of apple in a convective dryer. 
In this paper, the drying characteristics of kiwifruit were presented experimentally for kiwi samples $4 \mathrm{~mm}$ and $8 \mathrm{~mm}$ thick at air temperature of $45^{\circ} \mathrm{C}$ and air velocity of $0.5,1.0$ and $1.5 \mathrm{~m} / \mathrm{s}$ in a convective type dryer. For this purpose, an experimental setup was established and required measurements were performed.

\section{Experimental Study}

\subsection{Setup}

A new experimental dryer setup was constructed in order to perform the tests. Figure 1 shows a schematic view of convective type dryer.

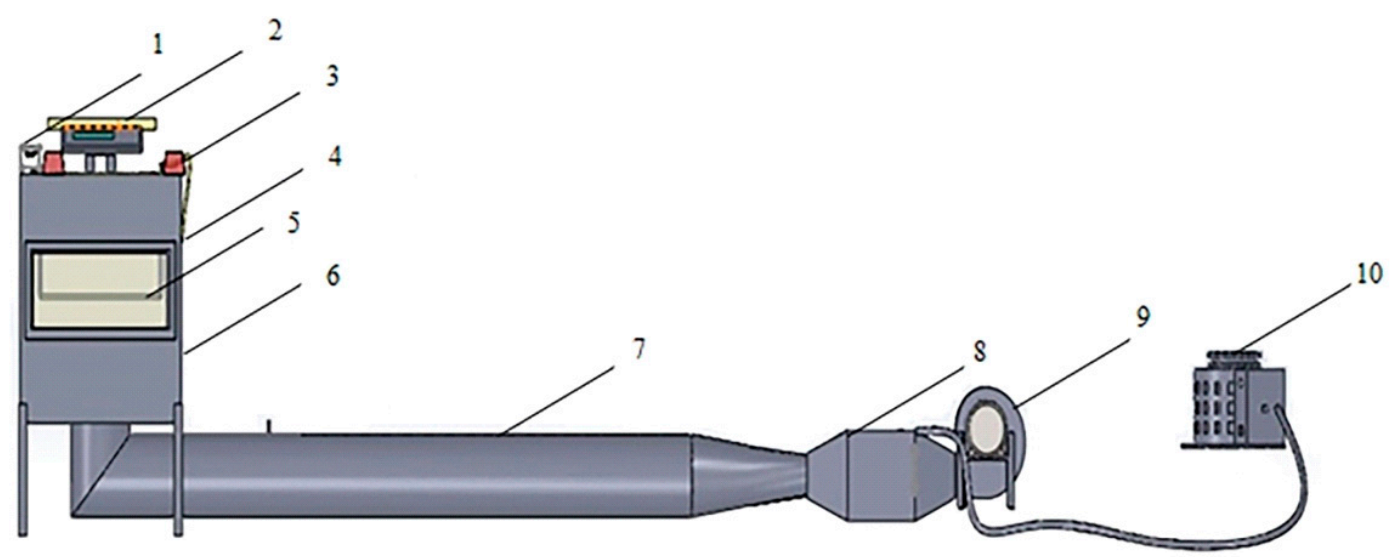

Figure 1. Setup (1. Hygrometer [HTC-1], 2. Precision scale (AVERY BERKEL, Model CC061), 3. Thermometer-Anemometer [KIMO], 4. Outlet, 5. Tray, 6. Chamber, 7. Air flow channel, 8. Heating system, 9. Fan [SB908AN-22-3], 10. Variac [STACO 3PN1520B]).

As seen in Figure 1, the setup includes fan, heater, drying cabinet, air flow duct, air inlet and outlet ducts, hygrometer, a digital scale with a measurement range of 0-6100 $\mathrm{g}$ with a sensitivity of $\pm 0.1 \mathrm{~g}$ to measure the mass loss of the product. The digital scale is $30 \mathrm{~cm}$ long, $19 \mathrm{~cm}$ in wide. A drying tray with a length of $27 \mathrm{~cm}$ and a width of $21 \mathrm{~cm}$ was manufactured to be connected to the scale and the products to be dried were placed on the tray and the product mass loss was read out at regular intervals. The drying room is in a shape of a rectangular prism with $60 \mathrm{~mm}$ length, $40 \mathrm{~mm}$ width, $60 \mathrm{~mm}$ height, and is made of a steel sheet with a thickness of $3 \mathrm{~mm}$. A hole with a diameter of $120 \mathrm{~mm}$ was made at the bottom of the cabinet and connected to the air flow duct. The hot air coming from the flow channel was aerated with the product from below and a $100 \mathrm{~mm}$ diameter duct was opened to the side surface of the cabinet to vent the warmed air. The air flow channel, which is connected to the drying room at the bottom, has a length of $2.5 \mathrm{~m}$ and is in a shape of a circular diameter of $120 \mathrm{~mm}$, and is made of a steel sheet with a thickness of $3 \mathrm{~mm}$. This channel is insulated with a glass wool with a thickness of $30 \mathrm{~mm}$ and the upper part is covered with aluminum tape. The temperature of the kiwi fruit and of the cabinet outlet can be determined by using the $\mathrm{T}$ type thermocouple by means of the temperature measurement tools located on the cabinet. The air flow rate was controlled by a radial fan with a power of $0.537 \mathrm{~kW}$. The radial fan has $50 \mathrm{~Hz}, 220 \mathrm{~V}$ and a currency of $2.5 \mathrm{~A}$. The fan used in the system is a constant speed $(2800 \mathrm{rpm})$. The heating system consists of wires with a power of $2000 \mathrm{~W}$, and the drying air temperature required for drying is fixed by means of a variac. The cabinet outlet temperature and the internal temperature of the product are measured by means of a thermometer with a measurement range of -20 to $+80^{\circ} \mathrm{C}$. The drying air velocity was determined by means of an anemometer with a measurement range of $0.15-3 \mathrm{~m} / \mathrm{s}$. The kiwi samples required to be dried were placed on the tray connected to the scale and the mass loss was recorded at 15 min intervals. The measuring instruments developed in this experimental work are showed in Table 2 with photos and technical specifications [19]. 
Table 2. Photos and technical specifications of the dryer [19].

\begin{tabular}{|c|c|c|}
\hline Unit & Technical Specification & Photos \\
\hline Drying chamber & $\begin{array}{c}\text { iron sheet (3 mm); length: } 60 \mathrm{~mm} \text {; width: } 40 \mathrm{~mm} \text {; } \\
\text { height: } 60 \mathrm{~mm} \text {. }\end{array}$ & \\
\hline Air flow channel & $\begin{array}{l}\text { galvanized sheet; length: } 2.5 \mathrm{~m} \text {; pipe diameter: } \\
120 \mathrm{~mm} \text {; insulation thickness } 30 \mathrm{~mm} \text {. }\end{array}$ & \\
\hline Precision scale & $\begin{array}{l}\text { Measurement range } 0-6100 \mathrm{~g} \text { and an accuracy of } \\
\pm 0,1 \mathrm{~g} \text {; digital scale length } 30 \mathrm{~cm} \text {; width } 19 \mathrm{~cm} \text {; } \\
\text { sample tray length } 27 \mathrm{~cm} \text {; width } 21 \mathrm{~cm} \text {. AVERY } \\
\text { BERKEL (Model CC061) }\end{array}$ & \\
\hline Radial Fan & $\begin{array}{l}0.537 \mathrm{~kW} \text { power; } 220 \mathrm{~V} ; 50 \mathrm{~Hz} ; 2.5 \mathrm{~A} \text {; } \\
28001 / \mathrm{min} \text { [SB908AN-22-3]. }\end{array}$ & \\
\hline Heating system & $2000 \mathrm{~W}$ heater placed inside duct & \\
\hline Thermometer-Anemometer & $\begin{array}{l}\text { Temperature measuring ranges: from }-20 \text { to } \\
+80^{\circ} \mathrm{C} \text {; Air velocity measuring ranges; } \\
\text { from } 0.15 \text { to } 3 \mathrm{~m} / \mathrm{s} \text {; sizes } 50-34.9 \mathrm{~mm} ; \\
\text { Thermocouple K, J or T [KIMO]. }\end{array}$ & \\
\hline Variac & $\begin{array}{l}\text { From } 0 \text { to }+260 \mathrm{~V} ; 2.5 \mathrm{~A} ; \\
50 \mathrm{~Hz} \text { [STACO 3PN1520B]. }\end{array}$ & \\
\hline $\begin{array}{l}\text { Hygrometer and temperature } \\
\text { measurement }\end{array}$ & $\begin{array}{c}\text { from } 0 \text { to }+45^{\circ} \mathrm{C}\left( \pm 5^{\circ} \mathrm{C}\right) \\
\text { from } 10 \text { to } 90 \% \mathrm{RH}( \pm 5 \% \mathrm{RH})[\mathrm{HTC}-1] \text {. }\end{array}$ & \\
\hline
\end{tabular}

\subsection{Data Reduction}

Moisture content is a measure of relative humidity present in the sample. Moisture content is offered in two forms, wet base and dry base [20]. While moisture content according to wet base:

$$
M_{w b}=\frac{M_{w}}{M_{T}}
$$


expressed by the equation above, moisture content according to dry base:

$$
M_{d b}=\frac{M_{w}}{M_{k}}
$$

is shown by the equation above where $M_{w}$ is the water mass of the sample, $M_{T}$ is the total mass of the sample, and $M_{k}$ is the dry mass of the sample. The ratio of the moisture content of the mass at any given $t$ time to the moisture content at the beginning is called drying rate and can be expressed as follows:

$$
W_{s}=\frac{M_{t}-M_{e}}{M_{0}-M_{e}}
$$

is determined by the equation above where; $M_{t}$ is mass of the sample at considered time $t, M_{e}$ is mass of the equilibrium humidity of sample and $M_{0}$ is the initial mass of the sample.

The change of the moisture content in the dried product in unit time is called drying air velocity. The drying air velocity is calculated by the expressed equation:

$$
\frac{d W}{d t}=\frac{M_{t}-M_{t+\Delta t}}{\Delta t}
$$

where $M_{t+\Delta t}$ is the weight of the product at the $t+\Delta t$ time.

\subsection{Material and Methods}

Fresh kiwi fruits used in the experiment are harvested in Elazig province. Since they were grown in accordance with organic agriculture methods, no chemical substances such as synthetic fertilizer and pesticide were used. Ripe and sound kiwi were harvested by hand and stored in a refrigerator at $4{ }^{\circ} \mathrm{C}$ until drying experiments. After $3 \mathrm{~h}$ stabilization at ambient temperature, homogenous samples $(142 \mathrm{~g})$ were washed with tap water and hand peeled, cored with a knife and then cut vertical to their axis into cylindrical slices of 4 and $8 \mathrm{~mm}$ thickness using with a mechanical cutter. In order to determine color differences after drying, the kiwi slices were also dried in their natural form, which was called as untreated samples. About $142 \mathrm{~g}$ samples of kiwi slices were used for drying measurement. The drying was carried out to final moisture content of $10 \%$ from initial moisture content of about $80 \%$.

\section{Results and Discussions}

\subsection{Results of Experiments}

The experiments examining the effect of air velocity on drying in the drying process of the kiwifruit were carried out for $0.5,1.0$ and $1.5 \mathrm{~m} / \mathrm{s}$ of air at $45^{\circ} \mathrm{C}$ and a relative humidity of $10 \%$. Fresh kiwi samples with slice thickness of $4 \mathrm{~mm}$ and $8 \mathrm{~mm}$ were used in the experiments. The dryer was adjusted to be selected drying air temperature for about one an hour prior to the start of experiment to achieve the steady-state conditions. Fresh kiwi fruits were used in this study. Achieving $3 \mathrm{~h}$ stabilization under the ambient temperature conditions, homogenous samples were first hygienized then cored with a knife and then cut vertically to their axis into cylindrical slices of 4 and $8 \mathrm{~mm}$ thickness by a mechanical cutter. Then $142 \mathrm{~g}$ of kiwifruit was placed on the drying tray. The mass loss of the kiwifruit during drying was measured from the scale for every $15 \mathrm{~min}$. The chamber was installed under the laboratory conditions that were a relative humidity of between $20 \%$ and $45 \%$ and a temperature of between 22 and $28{ }^{\circ} \mathrm{C}$. The drying was carried out to final moisture content of $10 \%$ from initial moisture content of about $80 \%$.

View of kiwi fruits used in this study given in Figure 2a-c. The drying phases of the kiwifruit are photographed. Fresh kiwifruits used in this study are given in Figure 2a the kiwi samples placed in the drying cabinet are shown in Figure $2 b$ (on the left); dried kiwi samples are shown in Figure $2 b$ (on the right). The dried kiwi samples with thickness of $4 \mathrm{~mm}$ and $8 \mathrm{~mm}$ are shown in Figure 2c. 

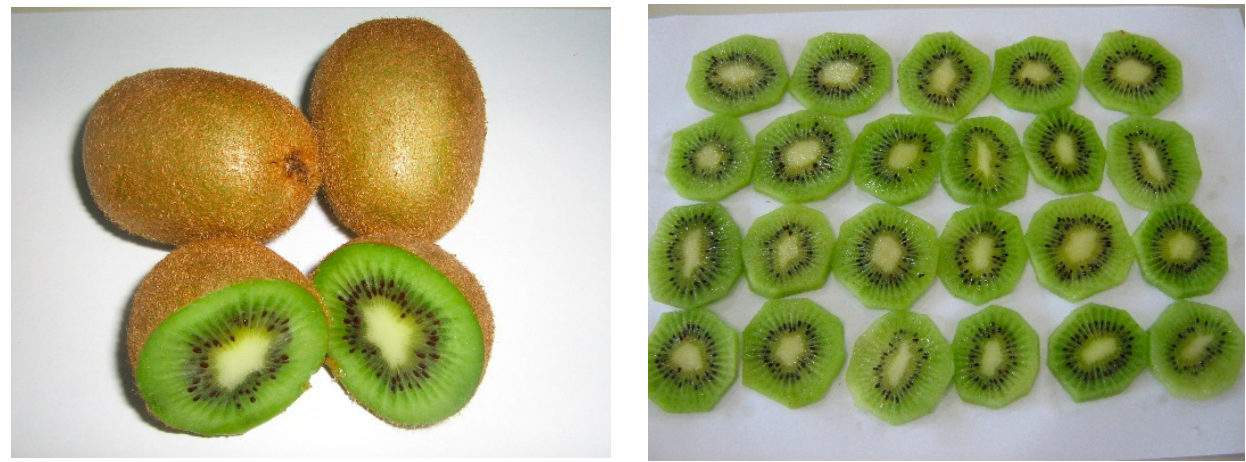

(a)
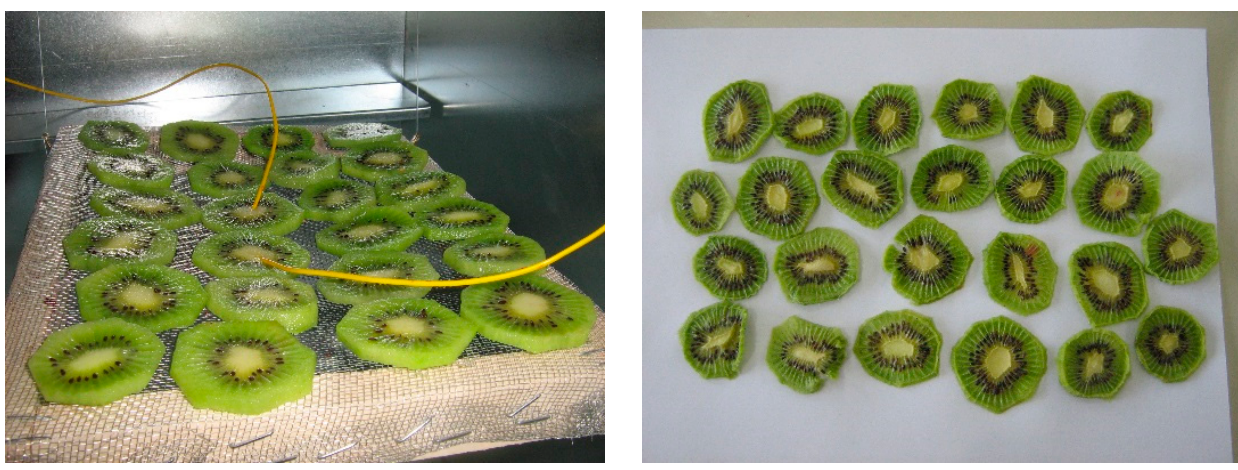

(b)
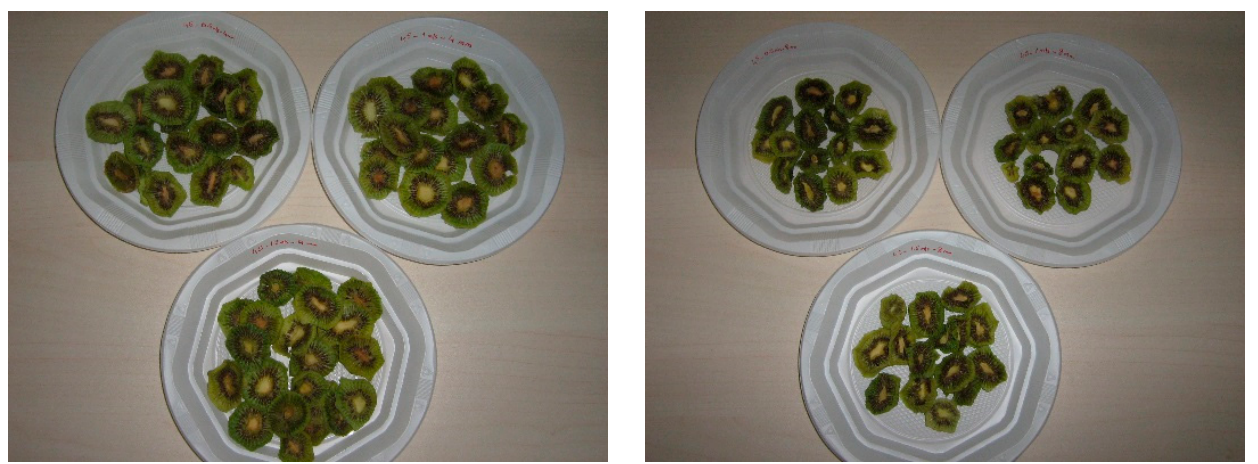

(c)

Figure 2. View of kiwi fruits used in this study, (a) Fresh kiwi fruits, (b) The view of the kiwi fruits in the dryer chamber (in left) and the view of the dried kiwi fruits (in right), (c) The view of the dried kiwi fruits for slice thickness of $4 \mathrm{~mm}$ (in left) and dried kiwi fruits for slice thickness of $8 \mathrm{~mm}$ (in right).

The moisture content of the product, as a function of drying time, is shown in Figure 3 for the kiwifruit with a thickness of $4 \mathrm{~mm}$, the drying air temperature of $45^{\circ} \mathrm{C}$ and the drying air velocity of $0.5 \mathrm{~m} / \mathrm{s}, 1 \mathrm{~m} / \mathrm{s}$ and $1.5 \mathrm{~m} / \mathrm{s}$. As seen from the drying curves, the drying air velocity has affected the moisture content of the kiwifruit. The lowest drying time $(225 \mathrm{~min})$ was achieved with a thickness of $4 \mathrm{~mm}$ and a drying speed of $1.5 \mathrm{~m} / \mathrm{s}$. The highest drying time (360 min) was obtained for a thickness of $4 \mathrm{~mm}$ and a drying speed of $0.5 \mathrm{~m} / \mathrm{s}$.

The moisture content of the product, as a function of drying time, is shown in Figure 4 for the kiwi fruit with a thickness of $8 \mathrm{~mm}$, the drying air temperature of $45^{\circ} \mathrm{C}$ and the drying air velocity of $0.5 \mathrm{~m} / \mathrm{s}, 1 \mathrm{~m} / \mathrm{s}$ and $1.5 \mathrm{~m} / \mathrm{s}$. The lowest drying time (420 $\mathrm{min})$ was achieved with a thickness of $8 \mathrm{~mm}$ and a drying speed of $1.5 \mathrm{~m} / \mathrm{s}$. The highest drying time $(750 \mathrm{~min})$ was found for a thickness of $8 \mathrm{~mm}$ and a drying speed of $0.5 \mathrm{~m} / \mathrm{s}$. This value is followed by $540 \mathrm{~min}(8 \mathrm{~mm}$ and $1 \mathrm{~m} / \mathrm{s})$. 


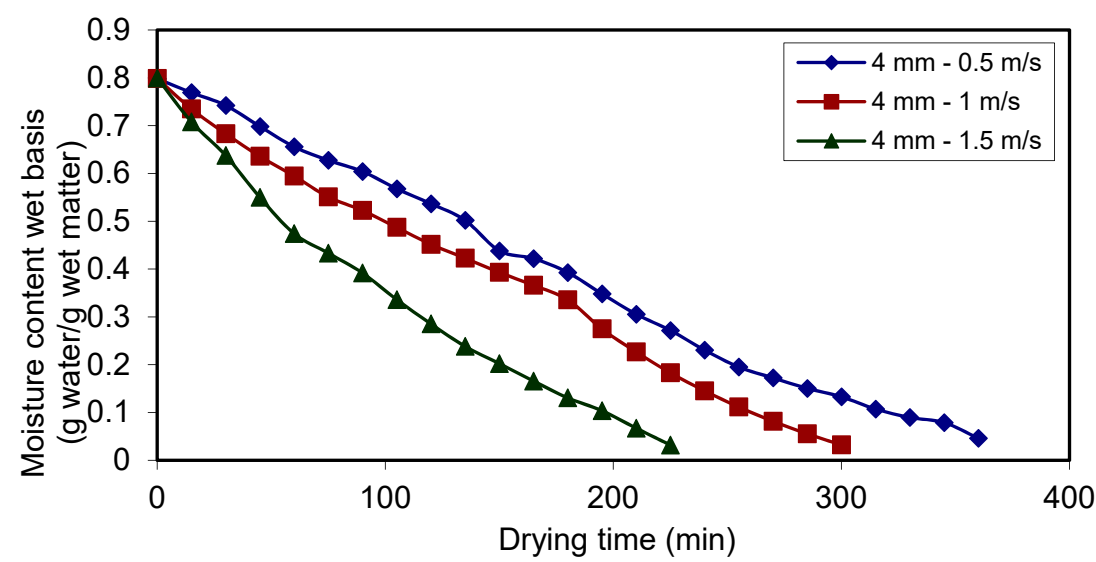

Figure 3. Moisture content wet basis as a function of drying time for drying air velocity of $0.5,1$ and $1.5 \mathrm{~m} / \mathrm{s}$ and slice thicknesses of $4 \mathrm{~mm}$ for kiwi fruits.

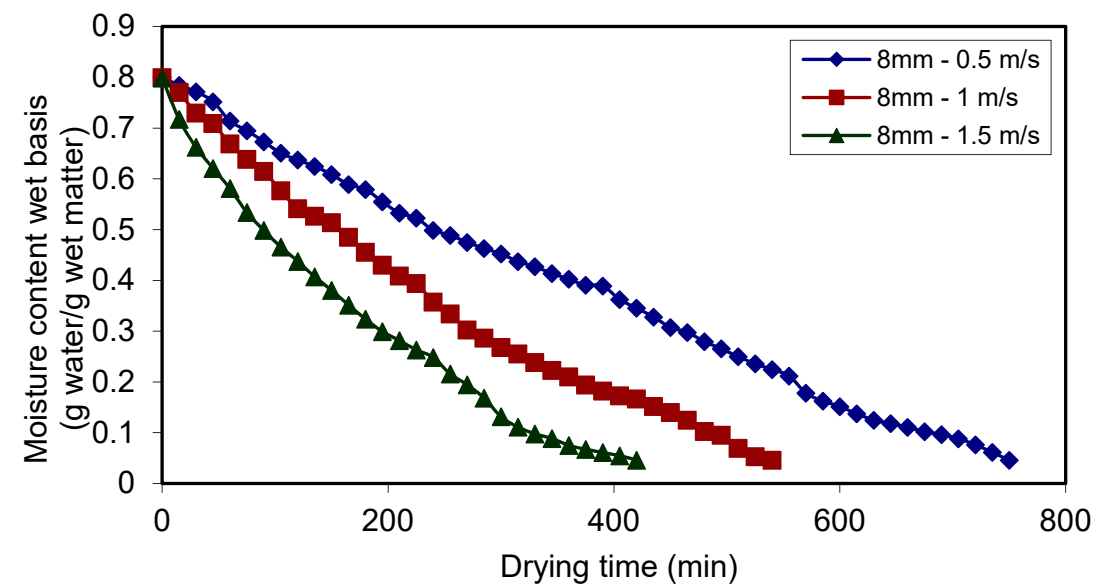

Figure 4. Moisture content wet basis as a function of drying time for drying air velocity of $0.5,1$ and $1.5 \mathrm{~m} / \mathrm{s}$ and slice thicknesses of $8 \mathrm{~mm}$ for kiwi fruits.

Figures 5 and 6 , as a function of drying time, shows the change in drying rate. This change was given for the kiwifruit with a thickness of $4 \mathrm{~mm}$ and $8 \mathrm{~mm}$ and air temperature of $45^{\circ} \mathrm{C}$ at air velocity of $0.5,1$ and $1.5 \mathrm{~m} / \mathrm{s}$. The drying rate decreases continuously with increasing drying time. It was tested that the main factor influencing drying rate is the drying air velocity, as reported in earlier studies [21,22].

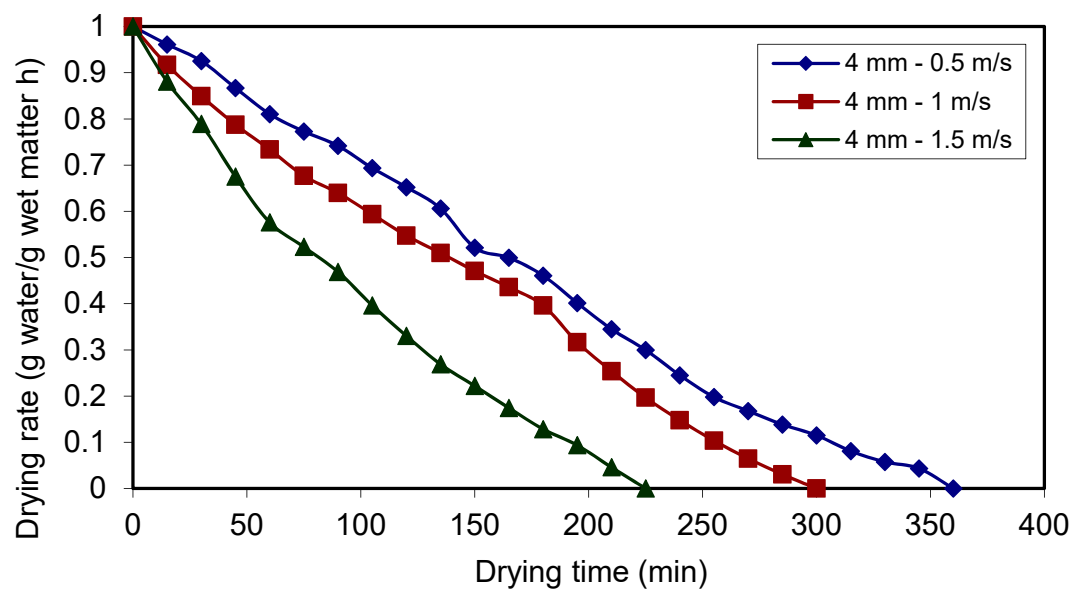

Figure 5. Drying rate as a function of drying time for drying air velocity of $0.5,1$ and $1.5 \mathrm{~m} / \mathrm{s}$ and slice thicknesses of $4 \mathrm{~mm}$ for kiwi fruits. 


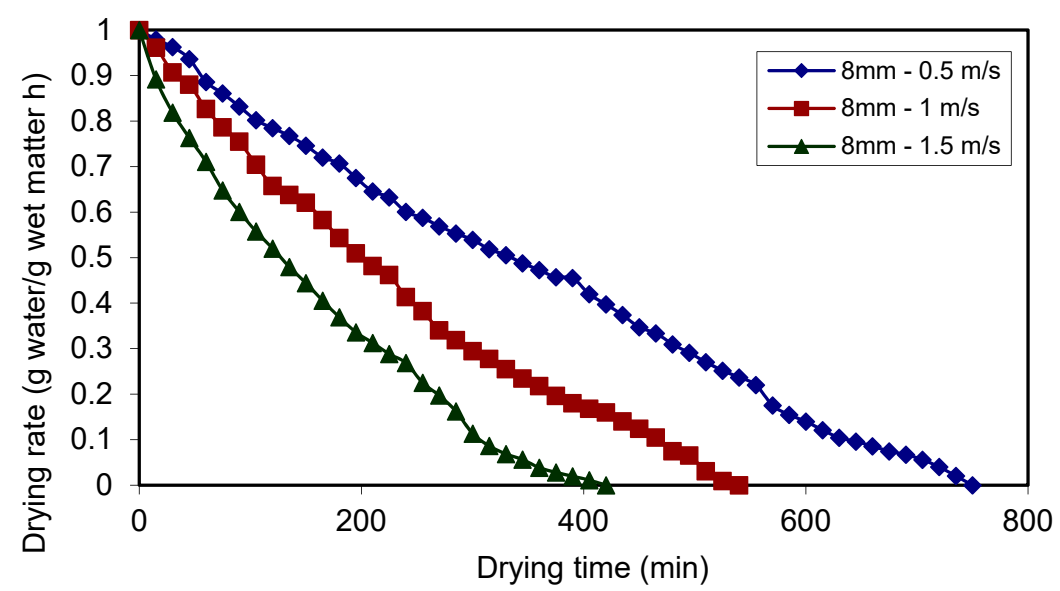

Figure 6. Drying rate as a function of drying time for drying air velocity of $0.5,1$ and $1.5 \mathrm{~m} / \mathrm{s}$ and slice thicknesses of $8 \mathrm{~mm}$ for kiwi fruits.

The internal temperature of the product is shown in Figure 7 for the kiwifruit with a thickness of $4 \mathrm{~mm}$, air temperature of $45^{\circ} \mathrm{C}$ at a drying air velocity of $0.5 \mathrm{~m} / \mathrm{s}, 1 \mathrm{~m} / \mathrm{s}$ and $1.5 \mathrm{~m} / \mathrm{s}$. The surface temperature of kiwifruit was constantly recorded during drying experiments from the scale for every $15 \mathrm{~min}$. The surface temperature increases rapidly and behind becomes steady slowly with the increasing drying time. When the drying time reached the end, the lowest temperature for kiwifruit was $37.1^{\circ} \mathrm{C}(4 \mathrm{~mm}, 0.5 \mathrm{~m} / \mathrm{s})$ and the highest temperature was $39.5^{\circ} \mathrm{C}(4 \mathrm{~mm}, 1.5 \mathrm{~m} / \mathrm{s})$. It was showed that the influencing surface temperature of harvest is the drying air velocity, as presented in old studies by Karim and Hawlader for banana [16].

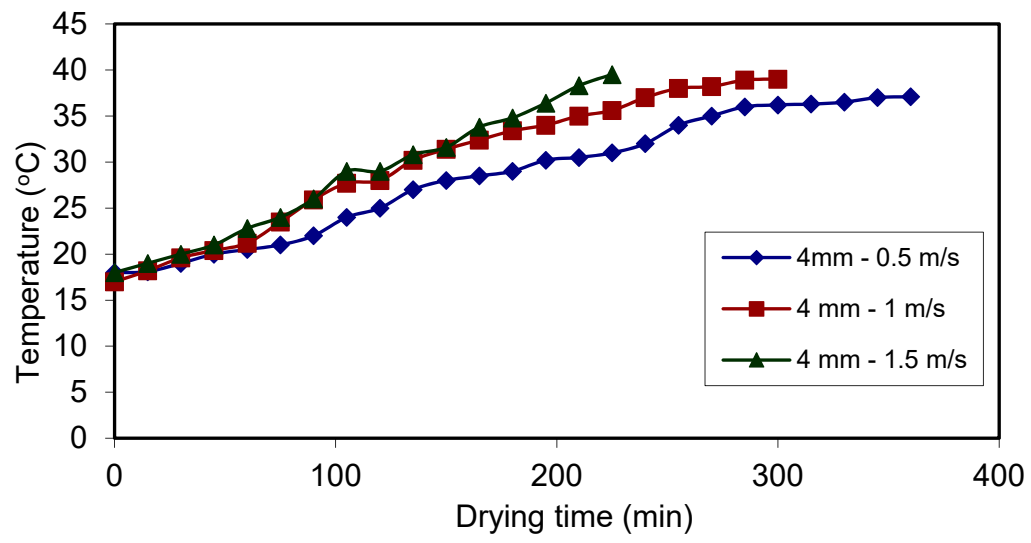

Figure 7. Surface temperature as a function of drying time for drying air velocity of $0.5,1$ and $1.5 \mathrm{~m} / \mathrm{s}$ and slice thicknesses of $4 \mathrm{~mm}$ for kiwi fruits.

The internal temperature of the product is shown in Figure 8 for the kiwifruit with a thickness of $8 \mathrm{~mm}$, air temperature of $45^{\circ} \mathrm{C}$ at a drying air velocity of $0.5 \mathrm{~m} / \mathrm{s}, 1 \mathrm{~m} / \mathrm{s}$ and $1.5 \mathrm{~m} / \mathrm{s}$. The surface temperature of the kiwifruit was recorded during drying and it was shown that the surface temperature increased rapidly and then became constant. The drying time to reach the final the lowest temperature for kiwi fruit were $39^{\circ} \mathrm{C}(8 \mathrm{~mm}, 0,5 \mathrm{~m} / \mathrm{s})$, the highest temperature for kiwi fruit were $42.4^{\circ} \mathrm{C}(8 \mathrm{~mm}$, $1.5 \mathrm{~m} / \mathrm{s})$. This value is followed by $40.9^{\circ} \mathrm{C}(8 \mathrm{~mm}, 1 \mathrm{~m} / \mathrm{s})$.

Mass loss of the products as a function of drying time are shown in Figure 9 for $45{ }^{\circ} \mathrm{C}$ air temperatures and for $0.5 \mathrm{~m} / \mathrm{s}, 1 \mathrm{~m} / \mathrm{s}$ and $1.5 \mathrm{~m} / \mathrm{s}$ air velocity and kiwifruit slice thicknesses of $4 \mathrm{~mm}$ and $8 \mathrm{~mm}$. The lowest drying time (225 $\mathrm{min}$ ) was found at $4 \mathrm{~mm}$ slice thicknesses and $1.5 \mathrm{~m} / \mathrm{s}$. The highest drying time $(750 \mathrm{~min})$ was found at $8 \mathrm{~mm}$ slice thicknesses and $0.5 \mathrm{~m} / \mathrm{s}$ velocity. This value is followed by $540 \mathrm{~min}(8 \mathrm{~mm}, 1 \mathrm{~m} / \mathrm{s}), 420 \mathrm{~min}(8 \mathrm{~mm}, 1.5 \mathrm{~m} / \mathrm{s}), 360 \mathrm{~min}(4 \mathrm{~mm}, 0,5 \mathrm{~m} / \mathrm{s}), 300 \mathrm{~min}$ $(4 \mathrm{~mm}, 1 \mathrm{~m} / \mathrm{s})$, respectively. 


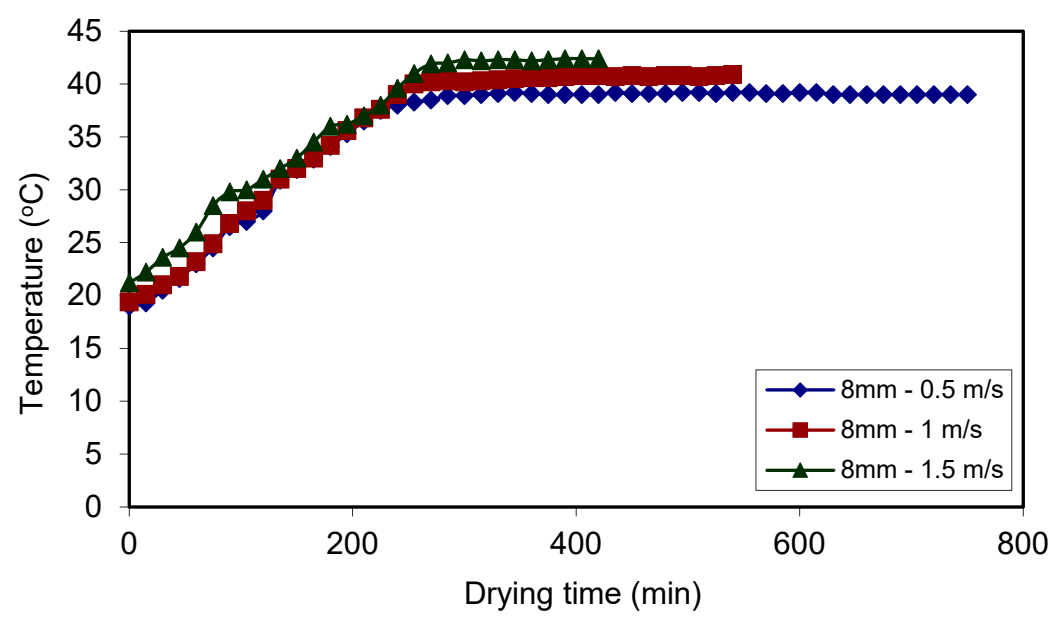

Figure 8. Surface temperature as a function of drying time for drying air velocity of $0.5,1$ and $1.5 \mathrm{~m} / \mathrm{s}$ and slice thicknesses of $8 \mathrm{~mm}$ for kiwi fruits.

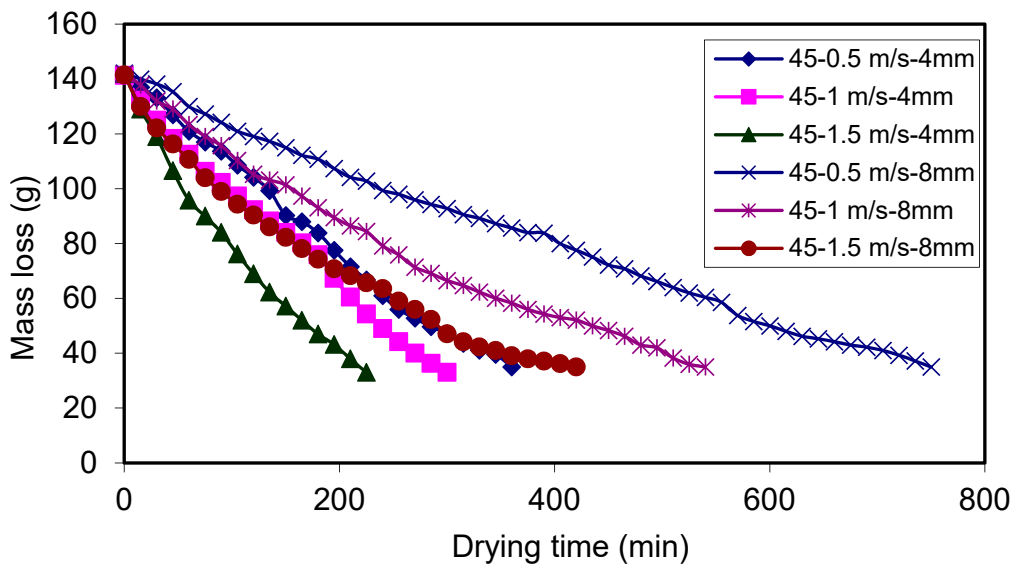

Figure 9. Mass loss of kiwi fruits at different slice thicknesses.

\subsection{Design Analysis and Analysis of Variance (ANOVA)}

Statistical approaches are used when experimental designs are applied to any system. However, experimental design techniques are not just related to statistics. These techniques are approaches that improve quality, reduce costs and significantly reduce the number of experiments by being used in all research and development activities. In this way resources are being used more efficiently, saving both time and material substantially. The parameters, or alias control factors, selected to enable this work to be performed are; thickness, speed, and drying time. The parameters and their levels are given in Table 3.

As design of experiment method, the Taguchi technique was used. In this method a statistical value known as the signal to noise $(S / N)$ ratio is used to analyze the results obtained from the experiments where $S$ refers to signal and $N$ refers to noise. The results obtained from the experiments are evaluated by converting them to the $S / N$ ratio. The $S$ is the actual value obtained from the system, and $N$ points out the factors that does not participate in the experiment design but has an effect on the experimental result. Noise sources are all variables that cause the value of the analyzed performance characteristic to deviate from the target value. So the smaller the $N$ value, the closer the target value is. For this reason, the purpose of this method is always to maximize the $S / N$ ratio. There are various $S / N$ ratios in the literature. In this study, it is desired that the humidity rate value we regard as performance characteristic is minimum. For this reason, the lower is better (LB) criterion is used.

The $S / N$ ratios calculated for the humidity rate and the orthogonal array $\mathrm{L}_{18}$ test design are given in Table 3. The averages of the $S / N$ ratios given in Table 3 are presented graphically in Figure 10. 
Table 3. $S / N$ ratio and control factors.

\begin{tabular}{ccccc}
\hline Experiment No. & \multicolumn{3}{c}{ Control Factors } & S/N Ratio \\
\hline 1 & $\mathrm{~A}$ & $\mathrm{~B}$ & $\mathrm{C}$ & \\
2 & 1 & 1 & 1 & 2.947656 \\
3 & 1 & 1 & 2 & 5.154078 \\
4 & 1 & 1 & 3 & 12.59733 \\
5 & 1 & 2 & 1 & 2.685227 \\
6 & 1 & 2 & 2 & 5.231762 \\
7 & 1 & 2 & 3 & 12.99799 \\
8 & 1 & 3 & 1 & 7.795295 \\
9 & 1 & 3 & 2 & 13.54313 \\
10 & 1 & 3 & 3 & 22.39837 \\
11 & 2 & 1 & 1 & 0.129565 \\
12 & 2 & 1 & 2 & 1.065896 \\
13 & 2 & 1 & 3 & 6.835554 \\
14 & 2 & 2 & 1 & 0.658958 \\
15 & 2 & 2 & 2 & 1.664354 \\
16 & 2 & 2 & 3 & 6.343403 \\
17 & 2 & 3 & 1 & 4.421369 \\
18 & 2 & 3 & 2 & 7.954719 \\
& 2 & 3 & 3 & 13.04653 \\
\hline
\end{tabular}

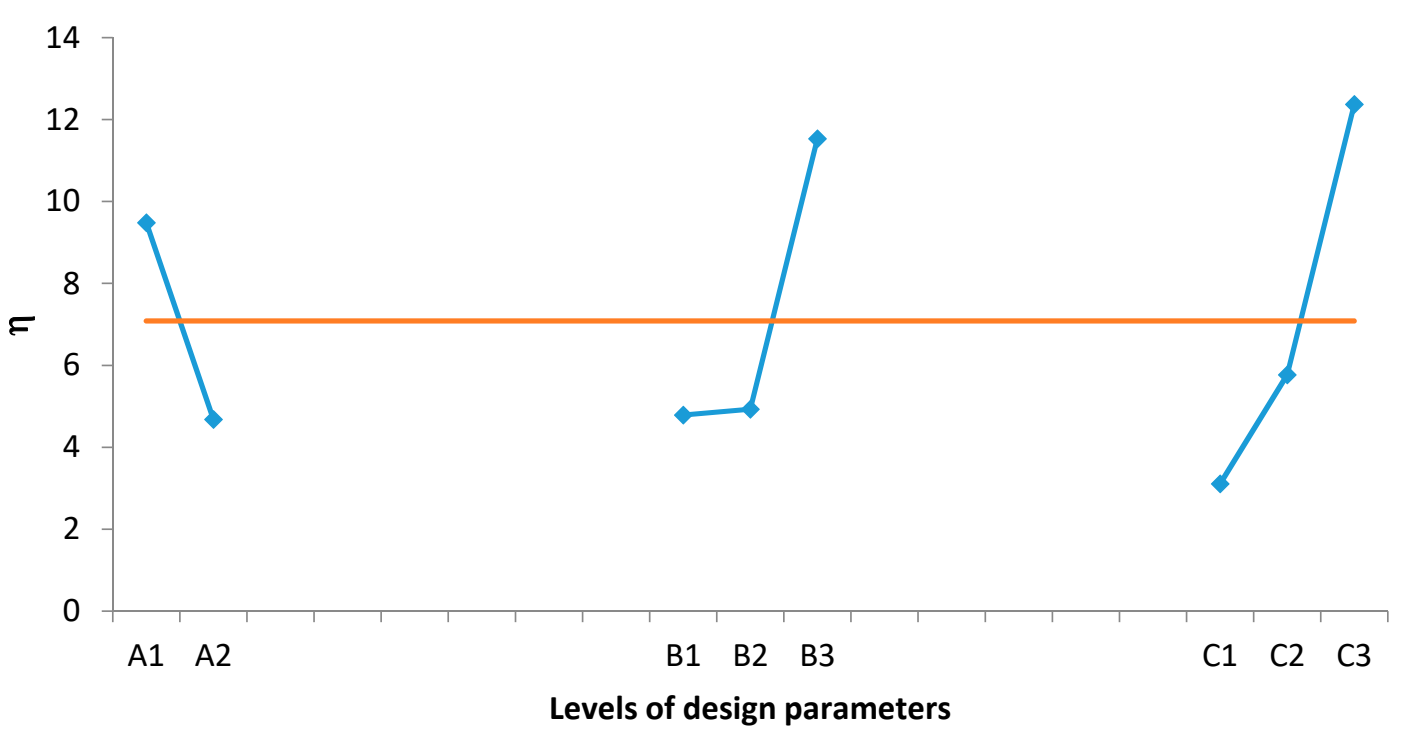

Figure 10. Average $\eta$ for humidity rate.

It was mentioned that the $S / N$ ratio has to be maximized at all times. In other words, optimum values always occur at the greatest $S / N$ ratios. Accordingly, when Figure 10 is examined it is clear that the optimum levels will take place in the case of A1B3C3. The optimum levels are shown in Table 4.

Table 4. Optimum levels of the variances.

\begin{tabular}{ccccc}
\hline & & \multicolumn{3}{c}{ Average S/N Ratios (dB) } \\
\hline Control factors & Level 1 & Level 2 & Level 3 & \\
A & Thickness of the slices (mm) & $9.48^{*}$ & 4.68 & - \\
B & Air velocity (m/s) & 4.79 & 4.93 & $11.53^{*}$ \\
C & Drying time (min) & 3.11 & 5.77 & $12.37^{*}$ \\
\hline
\end{tabular}

Average $S / N$ ratio $=7.08 \mathrm{~dB},{ }^{*}$ Optimum Level. 
The main purpose of applying ANOVA method is that, the effect of the parameters used in the experiments on the "humidity rate" which we have determined as the performance characteristic can be determined in percentages [23]. However, in order to determine whether the parameters used in the experiments have a statistically significant effect on the performance characteristic, an analysis called $F$ test is also required. The large value of the $F$ test means that the effect of the parameters studied on the performance characteristic is also significant. The statistical calculation method required for calculating this value is given in Appendix A.

The value of $F$ given in Appendix $A$ is found by dividing the variance of the parameter being considered by its variance of error. If the calculated values are greater than the tabular values in consequence of the comparison of the $F$ values with the appropriate reliability tables, it is concluded that the parameters have an effect on the performance characteristic which must be statistically accounted. In this study, in consequence of the comparison made according to the tables with $99 \%$ confidence level, it was seen that all the parameters provided this confidence level, and that is to say, they have effects on the results that must be accounted. The results of the analysis of variance (ANOVA) are exhibited in Table 5.

Table 5. Results of variance analysis.

\begin{tabular}{cccccc}
\hline Factor & $\begin{array}{c}\text { Degree of Freedom } \\
(\boldsymbol{d} f)\end{array}$ & $\begin{array}{c}\text { Sum of Square } \\
(\boldsymbol{S S})\end{array}$ & $\begin{array}{c}\text { Variance } \\
(\boldsymbol{V})\end{array}$ & $\boldsymbol{F}$ & $\begin{array}{c}\text { Contribution } \\
\mathbf{( \% )}\end{array}$ \\
\hline A & 1 & 103.8263775 & 103.8264 & 41.06048 & 17.31623091 \\
B & 2 & 177.8696111 & 88.93481 & 35.17128 & 29.54121585 \\
C & 2 & 272.9478971 & 136.4739 & 53.9717 & 45.79426629 \\
Error & 12 & 30.34344542 & 2.52862 & 0 & 7.348286946 \\
Total & & 584.9873311 & & & \\
\hline
\end{tabular}

* Significant at least $99 \%$ confidence level.

According to the ANOVA results; it was determined that the most important parameter affecting the amount of moisture was drying time with $45.79 \%$. Drying time was followed by speed with $29.54 \%$ and thickness with $17.32 \%$.

\section{Conclusions and Recommendations}

Drying conditions of the kiwi fruits were presented in a convective type air dryer at the air temperatures of $45^{\circ} \mathrm{C}$ and air velocity of $0.5,1$ and $1.5 \mathrm{~m} / \mathrm{s}$ and kiwifruit slice thicknesses of $4 \mathrm{~mm}$ and $8 \mathrm{~mm}$. Some important results obtained from this study can be listed as follows;

$\checkmark \quad$ The drying rate and the moisture content of the sample are affected by the thickness of the kiwifruit and the speed of the drying air. Increased drying air velocity and reduced fruit thickness cause drying time to be reduced.

$\checkmark$ The lowest drying time (225 min) was obtained at $4 \mathrm{~mm}$ slice thicknesses and $1.5 \mathrm{~m} / \mathrm{s}$. The highest drying time $(750 \mathrm{~min}$ ) was obtained at $8 \mathrm{~mm}$ slice thicknesses and $0.5 \mathrm{~m} / \mathrm{s}$ velocity.

$\checkmark$ The drying was carried out to final moisture content of $10 \%$ from initial moisture content of about $80 \%(w b)$.

$\checkmark \quad$ Freshly harvested kiwifruit was successfully dried in the convective dryer at different speeds and at different thicknesses. It has been determined that working the convective dryer at different speeds is advantageous in terms of preserving brightness and color quality.

$\checkmark \quad$ By applying ANOVA to the test results it was found that, the most dominant parameter affecting the amount of moisture was drying time with $45.79 \%$. Drying time was followed by air velocity with $29.54 \%$ and thickness of the slices with $17.32 \%$.

$\checkmark$ The taste quality of the samples are not tasted, hence this study gives only information about the drying process. Further nutrition analysis are recommended by the co-authors of this study. 
Author Contributions: For research articles with several authors, a short paragraph specifying their individual contributions must be provided. The following statements should be used "conceptualization, F.O.; methodology, F.O.; investigation, F.O. and N.C.; writing—original draft preparation, N.C.; writing—review and editing, N.C.

Conflicts of Interest: The authors declare no conflict of interest and the funders had no role in the design of the study; in the collection, analyses, or interpretation of data; in the writing of the manuscript, or in the decision to publish the results.

\section{Appendix A}

$$
\begin{gathered}
S S_{m}=\frac{\left(\sum \eta_{i}\right)^{2}}{n} \\
S S_{\text {factor }}=\frac{\sum \eta_{\text {factor }-i}^{2}}{N}-S S_{m} \\
S S_{T}=\sum \eta_{i}^{2}-S S_{m} \\
S S_{e}=S S_{T}-\sum S S_{A} \\
d f_{\text {total }}=n-1 \\
d f_{\text {factor }}=k-1 \\
V_{\text {factor }}=\frac{S S_{\text {factor }}}{d f_{\text {factor }}} \\
F_{\text {factor }}=\frac{V_{\text {factor }}}{V_{\text {error }}}
\end{gathered}
$$

where $S S_{T}$ is the total sums of squares, $S S_{m}$ is the sums of square due to the mean, $S S_{\text {factor }}$ is the sums of squares due to factor, $S S_{e}$ is the sum of squared due to error, $\eta_{\text {factor }-i}$ the sum of $i$ th level of factor, $N$ is the repeating number of each levels of factors, $d f$ is the number of degrees of freedom, $n$ is the number of the experiments, $k$ is the number of factor's level, $V_{\text {factor }}$ is the variance of the factor, $F_{\text {factor }}$ is the $F$-test value of the factor, $j$ is the number of experiments in the orthogonal array [23].

\section{Appendix B. NOMENCLATURE}

$\begin{array}{ll}M_{w} & \text { mass of water in the sample, } \mathrm{g} \\ M_{T} & \text { total mass of sample, } \mathrm{g} \\ M_{k} & \text { dry mass of sample, } \mathrm{g} \\ M w b & \text { moisture content according to wet basis, } \mathrm{g} / \mathrm{g} \\ M_{d b} & \text { moisture content according to dry basis, } \mathrm{g} / \mathrm{g} \\ M t & \text { mass at time } \mathrm{t} \text { of sample, } \mathrm{g} \\ M_{t+\Delta t} & \text { mass at time } t+\Delta t \text { of sample, } \mathrm{g} \\ M_{0} & \text { initial mass of undried sample, } \mathrm{g} \\ M_{\mathcal{e}} & \text { equilibrium moisture content of sample (g water } / \mathrm{g} \text { dry matter) } \\ n & \text { number of experiments } \\ S S_{e} & \text { sum of square due to error } \\ S S_{\text {factor }} & \text { sum of square due to factor } \\ S S_{m} & \text { mean sum of square } \\ S S_{T} & \text { total sum of square } \\ S / \mathrm{N} & \text { signal to noise ratio }(\eta) \\ \rho & \text { air density, } \mathrm{kg} / \mathrm{m}^{3} \\ v & \text { drying air speed, } \mathrm{m} / \mathrm{s} \\ V_{\text {factor }} & \text { variance of the factor } \\ W & \text { drying air velocity, } \mathrm{m} / \mathrm{s} \\ W_{S} & \text { drying rate, } \mathrm{g} \text { water } / \mathrm{g} \text { dry matter } \mathrm{h} \\ \Delta T & \text { temperature difference, } \mathrm{K}\end{array}$




\section{References}

1. Cerci, K.N.; Kavak Akpinar, E. Experimental determination of convective heat transfer coefficient during open sun and greenhouse drying of apple slices. J. Therm. Eng. 2016, 2, 741-747.

2. Togrul, I.T.; Pehlivan, D. Modelling of drying kinetics of single apricot. J. Food Eng. 2003, 58, 23-32. [CrossRef]

3. Nimmol, C.; Devahastin, S.; Swasdisevi, T.; Soponronnarit, S. Drying and heat transfer behavior of banana undergoing combined low-pressure superheated steam and far-infrared radiation drying. Appl. Therm. Eng. 2007, 27, 2483-2494. [CrossRef]

4. Sacilik, K.; Elicin, A.K. The thin layer drying characteristics of organic apple slices. J. Food Eng. 2006, 73, 281-289. [CrossRef]

5. Kavak Akpinar, E.; Midilli, A.; Bicer, Y. Single layer drying behavior of potato slices in a convective cyclone dryer and mathematical modelling. Energy Convers. Manag. 2003, 44, 1689-1705. [CrossRef]

6. Arslan, D.; Ozcan, M.M. Study the effect of sun, oven and microwave drying on quality of onion slices. LWT Food Sci. Technol. 2010, 43, 1121-1127. [CrossRef]

7. Brasiello, A.; Iannone, G.; Adiletta, G.; De Pasquale, S.; Russo, P.; Di Matteo, M. Mathematical model for dehydration and shrinkage: Prediction of eggplant's MRI spatial profiles. J. Food Eng. 2017, 203, 1-5. [CrossRef]

8. Proietti, N.; Adiletta, G.; Russo, P.; Buonocore, R.; Mannina, L.; Crescitelli, A.; Capitani, D. Evolution of physicochemical properties of pear during drying by conventional techniques, portable-NMR, and modeling. J. Food Eng. 2018, 230, 82-98. [CrossRef]

9. Gorinstein, S.; Haruenkit, R.; Poovarodom, S.; Park, Y.; Vearasilp, S.; Suhaj, M.; Ham, K.; Heo, B.; Cho, J.; Jang, H.G. The comparative characteristics of snake and kiwi fruits. Food Chem. Toxicol. 2009, 47, 1884-1891. [CrossRef]

10. Dalvand, M.J.; Mohtasebi, S.S.; Rafiee, S. Study on effective structural parameters on drying rate of kiwi fruits in a solar EHD dryer. Int. J. Multidiscip. Sci. Eng. 2012, 3, 66-70.

11. Mohammadi, A.; Rafiee, S.; Keyhani, A.; Emam-Djomeh, Z. Estimation of thin-layer drying characteristics of kiwifruit (cv. Hayward) with use of page's model. Am. Eurasian J. Agric. Environ. Sci. 2008, 3, 802-805.

12. Wang, $\mathrm{H}$.; $\mathrm{Ng}$, T.B. Isolation of an antifungal thaumatin-like protein from kiwi fruits. Phytochemistry 2002, 61, 1-6. [CrossRef]

13. Kaya, A.; Aydın, O.; Dincer, I. Experimental and numerical investigation of heat and mass transfer during drying of Hayward kiwi fruits (Actinidia deliciosa Planch). J. Food Eng. 2008, 88, 323-330. [CrossRef]

14. Singh, N.J.; Pandey, R.K. Convective air drying characteristics of sweet potato cube (Ipomoea batatas L.). Food Bioprod. Process. 2012, 90, 317-322. [CrossRef]

15. Guine, R.P.F.; Fernandes, R.M.C. Analysis of the drying kinetics of chestnuts. J. Food Eng. 2006, 76, 460-467. [CrossRef]

16. Karim, M.A.; Hawlader, M.N.A. Drying characteristics of banana: Theoretical modelling and experimental validation. J. Food Eng. 2005, 70, 35-45. [CrossRef]

17. Maskan, M. Kinetics of color change of kiwi fruits during hot air and microwave drying. J. Food Eng. 2001, 48, 169-175. [CrossRef]

18. Velic, D.; Planınic, M.; Tomas, S.; Bilic, M. Influence of airflow velocity on kinetics of convection apple drying. J. Food Eng. 2004, 64, 97-102. [CrossRef]

19. Ozgen, F. Experimental investigation of drying characteristics of cornelian cherry fruits (Cornus mas L.). Heat Mass Transf. 2015, 51, 343-352. [CrossRef]

20. Darici, S.; Şen, S. Investigation of effects of drying air velocity on drying at drying of kiwi (Kivi meyvesinin kurutulmasında kurutma havası hızının kurumaya etkisinin incelenmesi). Tesisat Mühendisliği 2012, 130, 51-58.

21. Doymaz, I. Air drying characteristics of tomatoes. J. Food Eng. 2007, 78, 1291-1297. [CrossRef]

22. Wang, J.; Xi, Y.S. Drying characteristics and drying quality of carrot using a two-stage microwave process. J. Food Eng. 2005, 68, 505-511. [CrossRef]

23. Celik, N.; Turgut, E. Design analysis of an experimental jet impingement study by using Taguchi method. Heat Mass Transf. 2012, 48, 1407-1413. [CrossRef]

(C) 2018 by the authors. Licensee MDPI, Basel, Switzerland. This article is an open access article distributed under the terms and conditions of the Creative Commons Attribution (CC BY) license (http://creativecommons.org/licenses/by/4.0/). 